The $B D J$ News section accepts items that include general news, latest research and diary events that interest our

readers. Press releases or articles may be edited, and should include a colour photograph if possible. Please direct your correspondence to the News Editor,

Arveen Bajaj at the BDJ, The Macmillan

Building, 4 Crinan Street, London N1 9XW

or by email to bdj@bda.org

\section{Specialists at} violence prevention conference

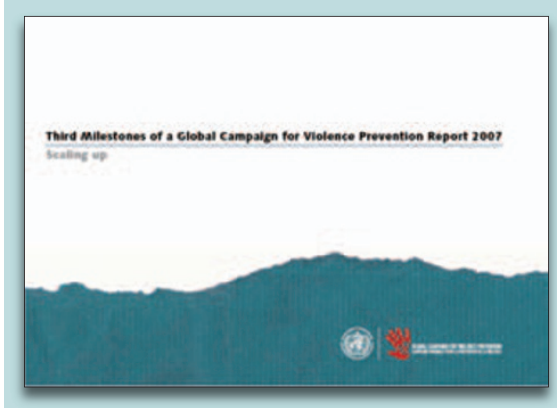

A workshop focusing on repeat admissions of those with violence-related facial injuries recently took place at the World Health Organization's third Milestones of a Global Campaign for Violence Prevention meeting in Fife. Two Glasgow University Dental School maxillofacial specialists, Professor Ashraf Ayoub, Director of Research and Professor of Oral \&t Maxillofacial Surgery, and Dr Christine Goodall, Clinical Lecturer in Oral and Maxillofacial Surgery, led the workshop Service-based prevention of repeat victimisation.

The workshop is based on a joint initiative between the Alcohol and Facial Injuries Research Group of Glasgow University Violence Reduction Unit, whereby nurses give counselling sessions to those who have received facial injuries as a result of alcoholrelated violence.

Dr Goodall said, 'I see the end result of violent behaviour every day and really feel that we have to stop just treating the injuries and start treating the causes. Being able to speak on the subject in front of an international audience will hopefully generate more interest in the initiative, leading to a scaling up of such work.'

\title{
Milestone reached
}

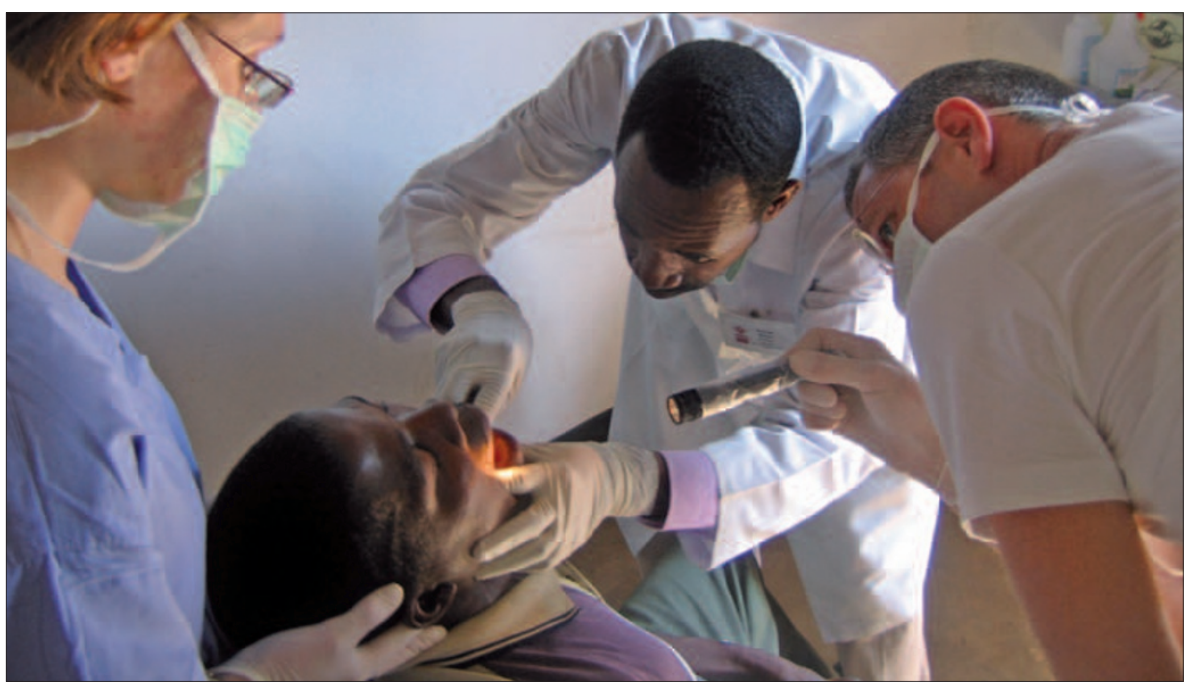

UK charity Bridge2Aid (B2A) has recently reached its quarter of a million mark, as safe emergency dental care in Tanzania is now available to more than 250,000 people. The charity has pioneered a training initiative over the past two years which uses UK volunteer dentists and nurses to train rural health workers in basic extraction techniques - a service in huge demand in the developing world.

The latest milestone in B2A's project was reached in June when the Dental Volunteer Programme (DVP) team trained another six Rural Clinical Officers (RCOs). This took the total number of RCOs trained to 34, representing over 250,000 people now having access to a trained person for emergency oral healthcare. B2A hope to increase the size of DVP and the RCO training during 2008. Subject to securing the necessary funding, they anticipate training at least $30 \mathrm{RCO}$ s during the year, helping to push on towards their goal of 500,000 people in Mwanza region gaining access to safe emergency oral healthcare by 2009 . For further information visit www.bridge2aid.org.

\section{Conflict of interest guidance}

New guidance from the GDC on how Council members, staff and others acting on behalf of the Council should manage their interests when undertaking their GDC roles came into effect on 1 July 2007.

It is the first time in the UK dental world that a document on managing interests has been published. The new guidance, Principles of managing interests, is a special edition in the Standards for dental professionals series. Its purpose is to remind each person involved in Council business of the need to question whether any of their interests may have an inappropriate influence on decisions that they make.

The GDC will keep a central register of the interests of members of the Council, all GDC committees and working groups, the Fitness to Practise Panel, Council-appointed inspectors and assessors and the Chief Executive and Registrar and other member of the Executive Management Team.

The register of interests will be publicly available at all GDC meetings and will be published on the GDC website www.gdc-uk.org. 


\section{Honorary fellowship awarded}

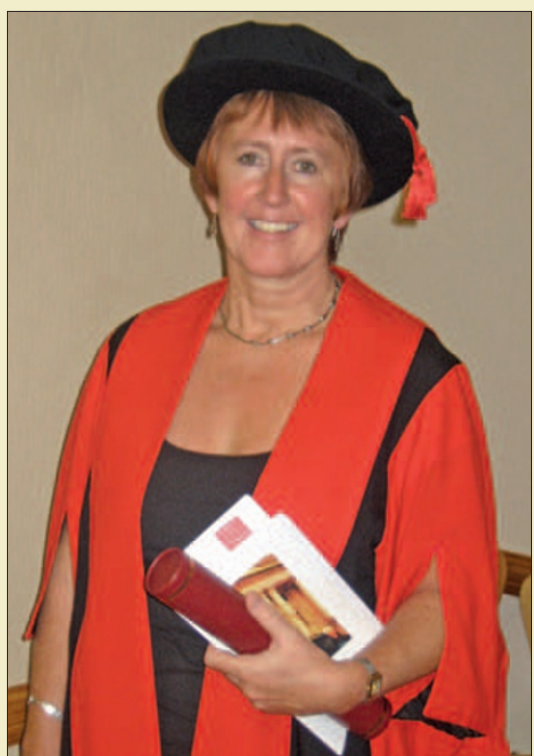

Dr Sue Greening, Immediate Past President of the BDA, was recently awarded an honorary fellowship by Cardiff University for her work in paediatric dentistry and the care of those with special needs.

A graduate of Cardiff Dental School, Dr Greening has always worked in the CDS in Wales and has a postgraduate qualification in Community Dental Practice from King's College, London. She was elected Chair of the main UK Committee for Community and Public Health Dentists at the British Dental Association from 1996 to 2003, and President of the British Society of Disability and Oral Health in 2000, after five years as its Honorary Secretary.

\section{Accolade for paper}

A paper published in the UK's Journal of Orthodontics has won the European Federation of Orthodontics (FEO) Award. The accolade is given to the best paper of any published in the national journal of a FEO member society in the previous year.

The paper, A randomized clinical trial comparing 'one-step' and 'two-step' orthodontic bonding systems by Nick Manning, Steve Chadwick, David Plunkett and Tatania Macfarlane was based around a randomised clinical trial comparing methods for bonding brackets to teeth.

\section{Appeal for help managing homeless dental service}

Every Christmas, the national homeless charity Crisis appeals through the BDA for dentists, dental nurses and hygienists to volunteer their skills to help homeless people. In 2006, over 75 dental professionals came together from the 23-30 December to run three surgeries at the Crisis Open Christmas centres in London.

In order to keep running this vital service, Crisis is in urgent need of help with managing the dental service. They are appealing for one or more dental professionals who can volunteer to help and advise with the set up and protocols and in particular with either managing or taking on the NHS contract that helps fund the service. Whilst as a charity their resources are limited, they are able to cover expenses.

If you might be able to help with the running of the service in any capacity, or if you have any questions, please contact Chris Clements, Crisis Open Christmas Services Manager at chris.clements@ crisis.org.uk or 0207426 3823. If you are interested in volunteering at Christmas, Crisis will start recruiting for Crisis Open Christmas volunteers in October 2007, with more information available from www.crisis.org.uk.

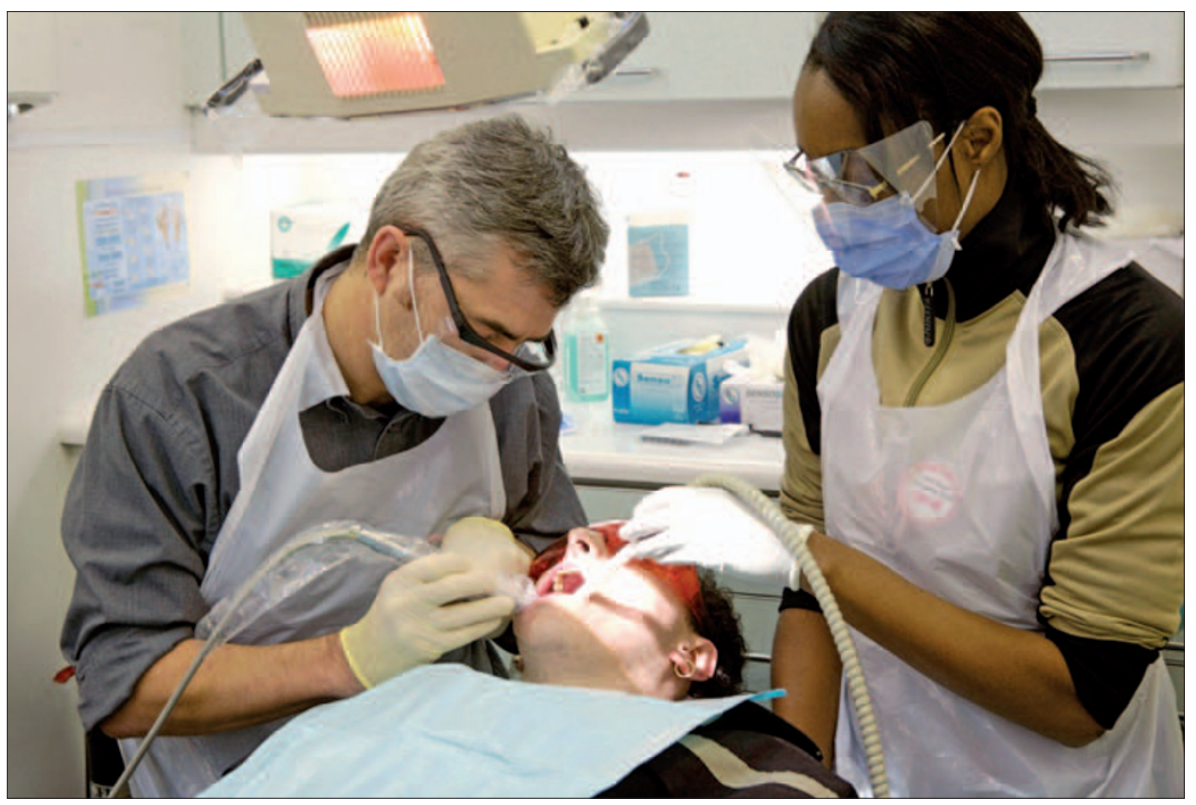

\section{Hidden sugar warning}

Too much added sugar in food is putting UK children's physical and oral health at risk, warns the Faculty of Public Health (FPH). With rising obesity levels, the FPH is calling on the food industry to reformulate its products to reduce the amounts of sugar added to food.

The dangers to health of excess sugar consumption are highlighted in a statement from the FPH, a public health body representing senior public health professionals. It says too much sugar can lead to obesity, increasing the risk of high blood pressure, diabetes, heart attacks and strokes, while eating sugary things too often can cause tooth decay and gum disease.

The organisation adds that children are the main cause of concern as the sugary snacks and drinks and sugar 'hidden' in savoury foods that they consume are contributing to the epidemic of childhood obesity and the high level of tooth decay, especially in the poorest families.

FPH President, Professor Alan Maryon Davis explained, 'Many people are not aware of how much hidden sugar there is in cereals, tinned beans, peas and vegetables, and soups and sauces. The food industry should use labelling that children can easily understand, such as the traffic-light scheme, and reformulate their foods to cut right down on added sugar. They've made a good start with salt and fat sugar is the next logical step.' 


\section{New visiting Professor}

Professor Alan Brook, Head of the Mechanisms of Oral Development and Disease Research Group at Liverpool University School of Dental Science has been appointed the Royal Society of Medicine Frohlich Visiting Professor to the USA. This award was made in open competition across all medical disciplines. The purpose of the award is to enhance research collaboration between UK and USA centres of excellence.

The links Alan Brook is developing in this role relate to studies on inherited defects of enamel and dentine. Advancing knowledge of the clinical phenotypes and aetiology of these uncommon and variable conditions aims to increase understanding of biomineralisation and thereby to enable improved, less invasive treatments.

The principal USA collaborator in the new network being formed from this appointment and associated funding is Professor Tim Wright of the University of North Carolina. Other collaborating centres in the USA are Alabama, Pennsylvania and Michigan. These studies also link in with those being undertaken in this field in Leeds, Liverpool, Manchester and Sheffield, led by Professor Jennifer Kirkham, Professor Mike Dixon and Professor Alan Brook.

These collaborative studies have

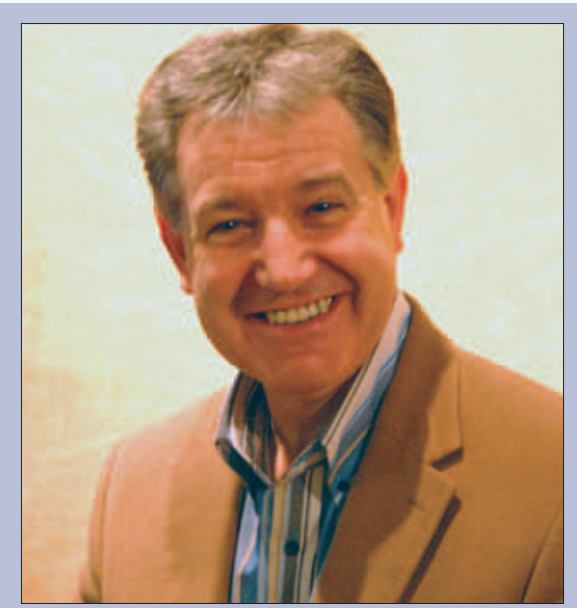

identified two new genetic mutations, enhancing understanding of the link between genetic control and the clinical phenotype in dental mineralisation.

\section{University helps with pharaoh's identity}

An Egyptian mummy whose identity had been in question has finally been identified with decisive evidence from a molar tooth in a wooden box inscribed with the mummy's name. Now DNA tests carried out on the mummy at the University of Manchester are expected to support the claim by Egyptian authorities that the remains are of ancient Egypt's most powerful female ruler Queen Hatshepsut.

Egyptologists in Cairo announced last month that a tooth found in a wooden box associated with Hatshepsut exactly fitted the jaw socket and broken root of the unidentified mummy. The box was found in 1881 in a cache of royal mummies collected and hidden away at the Deir al-Bahari temple about 1,000 metres (yards) away from the tomb where she was found.

Dr Angelique Corthals, a biomedical Egyptologist at the University of Manchester, says that DNA tests she helped carry out with colleagues at the National Research Centre in Cairo have promising preliminary results suggesting the identity of the queen.

Hatshepsut, meaning 'Foremost of Noble Ladies' was Egypt's greatest female ruler, having greater power than even Cleopatra. The fifth pharaoh of the 18th dynasty, her reign in the 15th century BC was longer than any other female ruler of an indigenous dynasty.

Most of the 18th dynasty royal mummies were moved away from their original tombs in the Valley of the Kings by

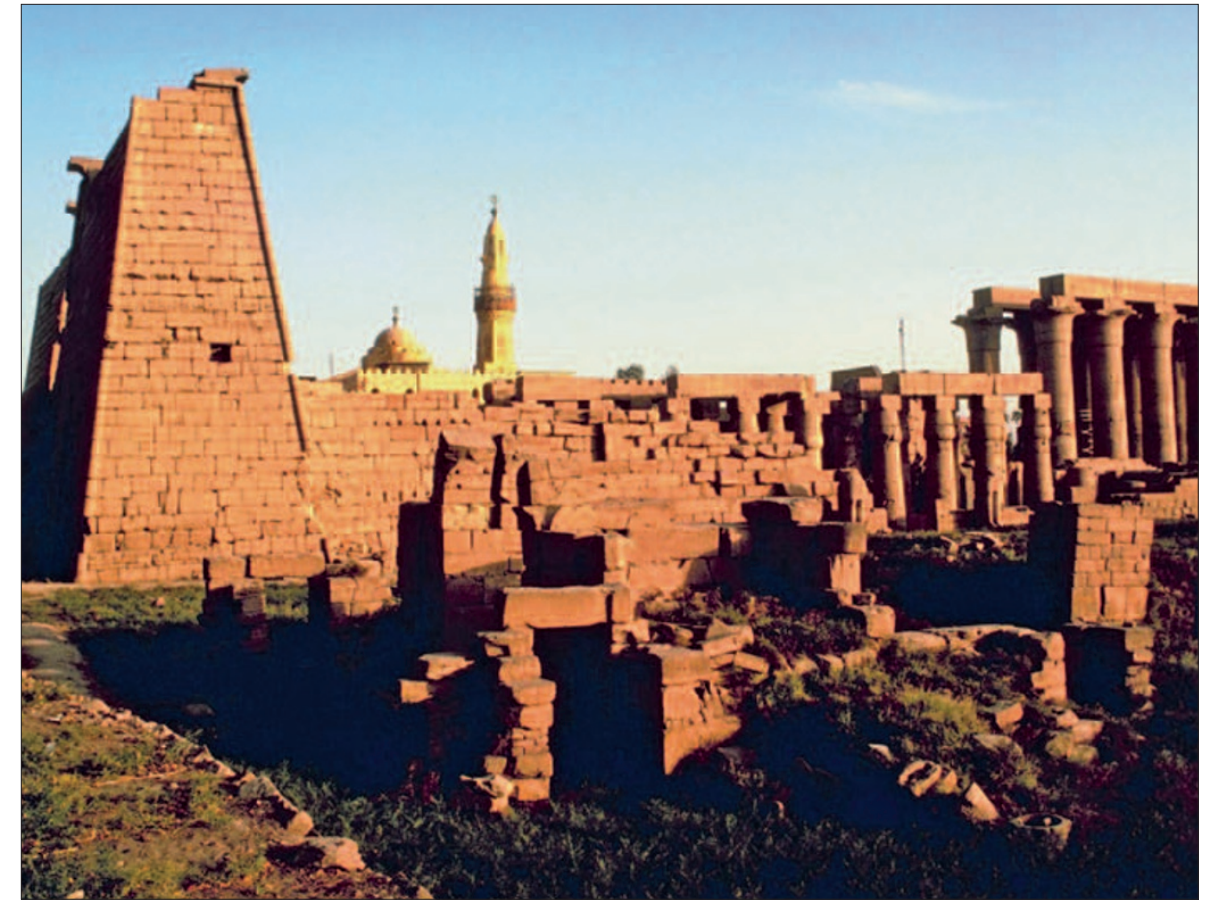

the priests of the 21st dynasty, fearing desecration and tomb robberies.

The cache was discovered in the 1870 s by the Razzul brothers and, in 1881, all 40 mummies were moved to Cairo. However, Hatshepsut's remains appeared to be missing and it was feared the mummy was lost, having been moved by her stepson Thutmose III, who - on succession - tried to destroy every trace of her reign. However, in 1903 a British archaeologist, Howard Carter, excavated what became known as tomb KV60 and discovered two mummies - one in a cof- fin inscribed for a royal nurse, the other stretched out on the floor. In June, Dr Zahi Hawass, Secretary General of the Supreme Council of Antiquities, held a news conference in Cairo to announce that this second mummy was that of the lost queen, pointing to the tooth as evidence.

The team is now planning to carry out more tests on the 40 remaining royal mummies, including that of Tutankhamun, in order to resolve the many questions surrounding the genealogy of the 18th and 19th dynasties. 


\section{DIARY}

September

FGDP (NW Region) Annual Study Day Date: 19 September 2007 Venue: Alder Hey Educational Centre, Liverpool

Email: louisecrees@mac.com

4th Annual Meeting of the European Society of Esthetic Dentistry Date: 21-23 September 2007 Venue: Vienna, Austria Email: iris.bobal@media.co.at www.escdonline.eu

American Dental Association Date: 27-30 September 2007 Venue: The Moscone Center, San Francisco, USA www.ada.org

\section{October}

British Society of Oral Implantology Date: 6 October 2007

Venue: The University of Glamorgan

Email:support@BSOl.org

www.BSOl.org

Oral Cancer: Challenges and Solutions Date: 6 October 2007

Venue: UCL Eastman Dental Institute, London

www.eastman.ucl.ac.uk

\section{BDTA Dental Showcase}

Date: 18-20 October 2007

Venue: NEC Birmingham

Tel: 01494789959

www.dentalshowcase.com

North of Scotland BDA Conference and Ceilidh

Date: 20 October 2007

Venue: Apex Hotel and Spa, Dundee Email: bdascotland@hotmail.com

Tel: +44 (0)1382635964

Annual meeting of the Society of Craniofacial Genetics \& American Society of Human Genetics

Date: 23 October 2007

Venue: Convention Center, San Diego, California, USA

www.craniofacialgenetics.org

FDI Annual World Dental Congress Date: 24-27 October 2007

Venue: Dubai, UAE

Email:congress@fdiworldental.org www.fdiworldental.org

\section{Campaign focuses on attitudes to dental services}

Patient and Public Involvement (PPI) Forums have launched a new national campaign - Dentistry Watch - to discover the experiences of the public, patients and dentists of current dental services.

The campaign aims to assess how easy it is for the public to access NHS dental services, what are patients' experiences of treatment, how much are they paying and gauge the views of dentists themselves.

Dentistry Watch, which is being supported by the Commission for Patient and Public Involvement in Health (CPPIH), has been prompted by a large number of Patient Forums who have identified issues surrounding NHS dental care within their local areas, following the introduction of the new Dental Contract in April 2006.

Laurence Wood, member of the PPI Forum for Leeds commented, 'In 2006 new measures came in to improve the provision of NHS dental care throughout England. These gave each Primary Care Trust (PCT) a duty to provide reasonable dental care services in their area to meet local patient demand. However, evidence suggests that numerous people are either unable to register with an NHS dentist close to their home, or do not know how to find one. Many PCTs are also struggling to find the budget to encourage private dental practices back into the NHS system due to lack of funding.'

Patients will be questioned throughout July and August and until 10th September. Both the local and national findings will be launched on 8 October 2007.

It is hoped that questioning patients, the general public and dentists will provide an accurate picture of NHS dental provision.

This includes whether it matches current government figures and the over all quality of care. The Dentistry Watch campaign comes on the back of the Care Watch and Food Watch campaigns, which highlighted patients' views on whether they had been treated with dignity whilst in hospital, and concerns over the quality of hospital food.

\section{Death notice}

Dr Ronald Cullen BDS, DDS, FRACDS unexpectedly but peacefully passed away on 23rd July 2007, at home aged 78 years. He formerly practised at Canford Cliffs, Poole and 1 Harley Street and was the dearly loved husband of Betty.

\section{Wrigley oral healthcare programme relaunch}

The Wrigley Oral Healthcare in Action programme has re-launched under the new name of Wrigley Oral Healthcare Programme. The new title falsl in line with the names of the 46 Wrigley Programmes running around the world, and members now receive a new set of practice materials. The dental programme is also adopting a theme and 2007 is the year of plaque.

To help combat lack of understanding amongst patients about plaque and its effect on oral health, Wrigley has introduced an Ask Me About Plaque campaign, which encourages patients to ask their dental professional about plaque
- what it is, why it needs to be controlled and removed and its importance to maintaining a good daily oral healthcare routine.

Supporting the campaign are a number of resources being offered free of charge to all new programme members including the Plaque Bulletin, the Plaque Patient Education Handbook and three patient leaflets providing information on healthy eating, dry mouth and plaque.

All existing members are required to re-join the programme under its new name. For more information visit www. BetterOralHealth.info, email wrigley@ ideaslondon.com or call 08000564563. 